\title{
ASSOCIATION BETWEEN THE SOCIAL RANK, BODY MASS, TESTICULAR CIRCUMFERENCE AND LINEAR BODY MEASURES OF RAMS
}

N. Maksimović ${ }^{1}$, M. Žujović ${ }^{1}$, S. Hristov ${ }^{2}$, M. P. Petrović ${ }^{1}$ B.
Stanković $^{2}$ Z. Tomić

${ }^{1}$ Institute for Animal Husbandry, Belgrade-Zemun, 11080, Serbia

${ }^{2}$ Faculty of Agriculture, University of Belgrade, Belgrade, Serbia

Corresponding author: nevena_maksimovic@yahoo.com

Original scientific paper

Abstract: The social rank refers to the relative position of an individual animal within the dominant hierarchy developed in a group. In rams, social rank is mostly associated with body mass, body size and body condition. However, although the body mass is generally considered as one of the main determinants of social rank, only few studies have been carried out for the purpose of associating of the social behaviour and body development of these animals. Objective of this research was to determine how the ram body development measures relate to establishment of social hierarchy. Social rank was established using food competition test at the age of animals between 4 and 17 months. Testing was done on total of 20 male animals of which number 12 animals were selected for further testing (6 dominant and 6 submissive animals). Body mass and testicular circumferences were measured at the age of 4, 7, 12 and 18 months, and linear body measures were taken at the age of 12 and 18 months. Dominant males had higher body mass and greater testicular circumference. The social rank had no significant effect on linear body measures of rams, except for chest girth $(\mathrm{P}<0.05)$ in both control periods. Body mass was moderately to highly positively associated with studied body parameters. Significant positive correlations were established between body mass and body length $(\mathrm{r}=0.58 ; \mathrm{P}<0.01)$, chest width $(\mathrm{r}=0.44$; $\mathrm{P}<0.05)$, chest girth $(\mathrm{r}=0.65 ; \mathrm{P}<0.01)$ and testicular circumference $(\mathrm{r}=0.62$; $\mathrm{P}<0.01$ ). Results obtained in this study indicate that it is justified to observe the body mass as one of the main determinants of social rank, as well as the possibility of earlier maturation of dominant animals.

Key words: rams, social rank, body mass, testicular circumference, body measures 


\section{Introduction}

In ruminants, social hierarchies are mainly associated with unequal access to various sources such as food, water, space, shade or to female animals. Social rank can be defined as relative position of an individual animal within a dominant hierarchy formed in a group (Pelletier and Festa-Bianchet, 2006). High social rank is achieved by teasing of other animals in the group, in so called dominance fights (Drews, 1993), and individual characteristics which mostly contribute to the competitive advantage during these fights are size of body and horns (Coltman et al.,2002; Preston et al.,2003).

Social rank is mainly associated with body mass (Pelletier and FestaBianchet, 2006; Ungerfeld and Gonsalez-Pensado, 2008), size of horns, body size and body condition of rams (Preston et al., 2003). These authors have also observed that dominant rams have greater testicular circumference and realize higher copulation rate and eventually more lambs. Rams with larger testicles, which is in high positive correlation with higher body masses (Mukasa-Mugerwa and Ezaz, 1992; Raji et al., 2008), have better sperm characteristics (Rege et $a l ., 2000)$ and better progeny. In most of ungulates, success in reproduction of male animals increases with the increase of social rank. In extensive sheep rearing, without planned breeding of animals, and where several rams are used in one herd, it is likely that a dominant hierarchy will develop where competition between rams can prevent submissive males from reproduction activities. Testosterone, steroid hormone produced in testicles, stimulates the development and growth of the skeleton and muscles, promotes secondary sex features and increases the aggressive behaviour - traits which can lead to increase of the competitive ability of rams (Sapolsky, 1993).

Also, social rank is often associated with the age in male and female animals (Cote, 2000; Pelletier et al., 2003). Older animals are larger and stronger, have more developed horns, but also have more experience compared to younger animals which also gives them the advantage. However, it is considered that in male animals, the body size and strength have far greater influence on establishment of dominant hierarchy than age (Pelletier and Festa-Bianchet, 2006), whereas in female animals the age is decisive.

Although the body mass is generally considered as main determinant of the social rank in male ungulates (Andersson, 1994; McElligott et al., 2001), only few studies have been carried out for the purpose of associating of the social behaviour and body development of these animals. In general, little is known about the determinants of individual rank of male animals of any ungulates (McElligott et al., 2001).

Considering this, main goal of this study was to investigate the association between the body size and mass measures and establishment of social hierarchy. 


\section{Material and method}

The study was carried out on Experimental sheep farm of the Institute for Animal Husbandry in Zemun on animals of MIS population which are three breed crosses (Wurtemberg, Il d'France and Pirot Pramenka) obtained in the process of complex combinational crossing. The trial included 20 male animals of same age, born during the same week as twins. Animals were weaned at the age of 2 months and subsequently held in one group until the end of the research. The research started when lambs were 4 months old.

The social rank was established using the food competition test (Sznott and Fulkerson, 1984; Ungerfeld and Gonsalez-Pensado, 2008). Animals were denied food for $12 \mathrm{~h}$ prior to testing, and subsequently they were given food to compete for, since it was placed in a bucket from which only one animal can eat. For testing, pairs of two animals were formed, i.e. 2 animals were released at the same time to compete for food. All potential pairs were formed of 20 animals, and each animal was tested only once per day. In the test, animal which managed to eat from the food bucket longer than 1 minute was marked as dominant (Lindsay et al., 1976). After testing all possible pairs, the index of their success was calculated based on number of tests where individual animal was marked as dominant or submissive. Test was carried out twice, at the age of 4 and 7 months. Based on the test 12 animals were selected (6 most dominant and 6 most submissive animals) for further testing.

Body mass and testicular circumferences were measured at the age of 4,7 , 12 and 18 months, and body measures were taken at the age of 12 and 18 months. Following body measures were included: height to withers, height to back, pelvis height, body length, chest width, chest depth, chest girth, leg and cannon circumference.

Statistical analysis of obtained data was done using the statistics package Statistica 8 for Windows (Stat Soft Inc). Body masses, testicular circumferences and body measures between dominant and submissive animals were compared using Mann-Whitney U test. Correlations between tested traits were determined using the Pearson's correlation coefficient..

\section{Results and Discussion}

Table 1 shows average values for body mass and testicular circumference of rams depending on their social rank. 
Table 1. Average values $( \pm$ se) of body mass and testicular circumference depending on the social rank

\begin{tabular}{|c|c|c|c|c|c|c|c|c|}
\hline \multirow[b]{2}{*}{ Rank } & \multicolumn{4}{|c|}{$\begin{array}{l}\text { Body mass }(\mathrm{kg}) \\
\bar{x} \pm s e\end{array}$} & \multicolumn{4}{|c|}{$\begin{array}{l}\text { Testicular circumference }(\mathrm{cm}) \\
\bar{x} \pm s e\end{array}$} \\
\hline & $\begin{array}{c}4^{\mathrm{ns}} \\
\text { months }\end{array}$ & $\begin{array}{c}7^{* *} \\
\text { months }\end{array}$ & $\begin{array}{c}12^{* *} \\
\text { months }\end{array}$ & $\begin{array}{c}18^{*} \\
\text { months }\end{array}$ & $\begin{array}{c}4^{\mathrm{ns}} \\
\text { months }\end{array}$ & $\begin{array}{c}7^{* *} \\
\text { months }\end{array}$ & $\begin{array}{c}12^{* *} \\
\text { months }\end{array}$ & $\begin{array}{c}18^{\mathrm{ns}} \\
\text { months }\end{array}$ \\
\hline Dominant & $36.83 \pm 1,85$ & $64.66 \pm 2,3$ & $7.83 \pm 2,7$ & $8.91 \pm 3,2$ & $3.08 \pm 1,4$ & $4.08 \pm 1,1$ & $6.16 \pm 1,0$ & $5.66 \pm 1.20$ \\
\hline Submissive & $33.75 \pm 2,17$ & $59.08 \pm 2,4$ & $1.08 \pm 3,0$ & $2.58 \pm 2,8$ & $2.08 \pm 0,8$ & $31.91 \pm 0,5$ & $3.75 \pm 0,9$ & $4.25 \pm 0.77$ \\
\hline
\end{tabular}

The body mass of dominant animals was higher than body mass of submissive animals during entire investigation period. The least difference in body mass was determined at the beginning of the investigation, at the age of 4 months $2.33 \mathrm{~kg}$ in favour of dominant animals $(\mathrm{P}>0.05)$. In the next three control periods the difference was significantly greater $-5.58,6.75$ and $6.33 \mathrm{~kg}$ in favour of dominant animals, which was statistically significant $(\mathrm{P}<0.05 ; \mathrm{P}<0.01)$. The testicular circumference was also higher in dominant animals. Significant effect of social rank on testicular circumference was established at the age of 7 and 12 months $(\mathrm{P}<0.01)$. In the first (4 months) and the last (18 months) control period, although present, established difference in testicular circumference was not statistically significant $(\mathrm{P}>0.05)$.

Obtained results confirm previously obtained research results also related to body mass (Pelletier and Festa-Bianchet, 2006; Ungerfeld and GonsalezPensado, 2008; Ungerfeld and Lacuesta, 2010) and increased testicular circumference in rams (Preston et al., 2003; Ungerfeld and Gonsalez-Pensado, 2008). Considering these results, data obtained in this study confirm the results of other authors (Andersson, 1994; McElligott et al.,2001) on considering the body mass of male animals as one of the major determinants of social rank. Also, greater increase of body mass and testicular circumference in dominant animals at earlier stage of development indicates faster sexual maturation of these animals.

Table 2 shows linear body measures of rams depending on the effect of social rank.

Based on data presented in Table 2, social rank had no significant influence on linear body measures in rams, except chest girth $(\mathrm{P}<0.05)$ in both control periods. Lobato and Beilharz (1979) have established significant positive correlation between social rank and chest girth in sheep of Corriedale breed, but not between the social rank and height to withers. Significant effect of social rank on chest girth, established also in the present study, can be associated with established significant correlation between social rank and body mass. 
Table 2. Average values ( \pm se) of linear body measures of rams depending on the effect of social rank

\begin{tabular}{|l|c|c|c|}
\hline \multirow{2}{*}{ Body measures (cm) } & Age (months) & Dominant & Submissive \\
\hline \multirow{2}{*}{ Height to withers } & $12^{\text {ns }}$ & $74.66 \pm 1.11$ & $73.83 \pm 1.40$ \\
\cline { 2 - 4 } & $18^{\text {ns }}$ & $79.08 \pm 0.77$ & $77.00 \pm 1.50$ \\
\hline \multirow{2}{*}{ Height to back } & $12^{\text {ns }}$ & $75.50 \pm 1.08$ & $75.00 \pm 1.23$ \\
\cline { 2 - 4 } & $18^{\text {ns }}$ & $78.58 \pm 0.73$ & $77.00 \pm 1.36$ \\
\cline { 2 - 4 } Pelvis height & $12^{\text {ns }}$ & $74.75 \pm 1.43$ & $74.00 \pm 1.29$ \\
\hline \multirow{2}{*}{ Body length } & $18^{\text {ns }}$ & $78.16 \pm 0.54$ & $76.33 \pm 1.11$ \\
\hline \multirow{2}{*}{ Chest width } & $12^{\text {ns }}$ & $84.58 \pm 1.06$ & $81.16 \pm 1.41$ \\
\cline { 2 - 4 } & $18^{\text {ns }}$ & $86.41 \pm 0.45$ & $23.91 \pm 0.52$ \\
\cline { 2 - 4 } Chest depth & $12^{\text {ns }}$ & $25.25 \pm 1.20$ & $24.41 \pm 0.47$ \\
\hline \multirow{2}{*}{ Chest girth } & $18^{\text {ns }}$ & $26.58 \pm 1.70$ & $32.08 \pm 0.74$ \\
\hline \multirow{2}{*}{ Leg circumference } & $18^{\text {ns }}$ & $32.41 \pm 0.72$ & $93.58 \pm 0.59$ \\
\cline { 2 - 4 } & $12^{*}$ & $33.25 \pm 0.62$ & $103.08 \pm 0.84$ \\
\hline $\begin{array}{l}\text { Cannon } \\
\text { circumference }\end{array}$ & $18^{\text {ns }}$ & $108.16 \pm 2.24$ & $54.83 \pm 1.37$ \\
\cline { 2 - 4 } & $18^{\text {ns }}$ & $54.00 \pm 2.03$ & $58.03 \pm 1.83$ \\
\hline \multirow{2}{*}{ P $<0.05$} & $12^{\text {ns }}$ & $57.91 \pm 1.09$ & $7.25 \pm 0.28$ \\
\hline
\end{tabular}

${ }^{*} \mathrm{P}<0.05$

${ }^{\mathrm{ns}}$ - no statistical significance

Enevoldsen and Kritensen (1997) have stated that the chest girth often is used as most reliable component for evaluation of body mass, Benyi (1997) has pointed out that chest girth in general is accepted as the most reliable growth variable, and Fourie et al. (2002) have established highly positive correlation $(\mathrm{r}=0.80)$ between body mass and chest girth in rams, which is confirmed by results of the present study (table 3 ).

Table 3 shows the values of correlation coefficients between body mass, testicular circumference and linear body measures of rams.

Table 3. Correlations between body mass, testicular circumference and linear body measures of rams

\begin{tabular}{|c|c|c|}
\hline Measures & Body mass & Testicular circumference \\
\hline Height to withers & $0.34^{\mathrm{ns}}$ & $0.16^{\mathrm{ns}}$ \\
\hline Height to back & $0.21^{\mathrm{ns}}$ & $0.17^{\mathrm{ns}}$ \\
\hline Pelvis height & $0.36^{\mathrm{ns}}$ & $0.13^{\mathrm{ns}}$ \\
\hline Body length & $0,58^{* *}$ & $0.20^{\mathrm{ns}}$ \\
\hline Chest width & $0.44^{*}$ & $0.42^{*}$ \\
\hline Chest depth & $0.34^{\mathrm{ns}}$ & $0.02^{\mathrm{ns}}$ \\
\hline Chest girth & $0.65^{* *}$ & $0.50^{*}$ \\
\hline Leg circumference & $0.27^{\mathrm{ns}}$ & $0.09^{\mathrm{ns}}$ \\
\hline Cannon circumference & $0.49^{*}$ & $0.18^{\mathrm{ns}}$ \\
\hline Testicular circumference & $0.62^{* *}$ & - \\
\hline
\end{tabular}


Body mass was moderately to highly positively correlated with studied body parameters. Significant positive correlations were established between body mass and body length $(\mathrm{r}=0.58 ; \mathrm{P}<0.01)$, chest width $(\mathrm{r}=0.44 ; \mathrm{P}<0.05)$, chest girth $(\mathrm{r}=0.65 ; \mathrm{P}<0.01)$ and testicular circumference $(\mathrm{r}=0.62 ; \mathrm{P}<0.01)$. Obtained correlations were lower than those stated by Mangistie et al. (2010) for height to withers $(\mathrm{r}=0.67)$, body length $(\mathrm{r}=0.78)$ and chest girth $(\mathrm{r}=0.86)$, established in sheep. Of all body dimensions, the strongest correlation was established between body mass and chest girth, which is in accordance with results of Afolayan et al. (2006) and Mengistie et al. (2010), also between body mass and testicular circumference, where the value of determined correlation coefficient between the two traits was higher compared to the value stated by Abbasi and Ghafouri-Kesbi (2011) $(\mathrm{r}=0.46)$. High and significant correlation coefficients between body mass and testicular circumference were established by Elmaz et al. (2007) (r=0.89) and Koyuncu et al. (2005) ( $\mathrm{r}=0.84)$.

Testicular circumference had low to moderately positive correlations with studied parameters. Significant moderate correlation $(\mathrm{P}<0.05)$ was established between testicular circumference and chest width $(\mathrm{r}=0.42)$, i.e. chest girth $(\mathrm{r}=0.50)$. Moderate positive correlation between testicular circumference and chest girth $(\mathrm{r}=0.46)$ was established by Hibret et al. (2001), Fourie et al. (2002) $(\mathrm{r}=0.47)$, as well as Abbasi and Ghafouri-Kesbi (2011) ( $\mathrm{r}=0.35$ ), who also established moderate positive correlations between testicular circumference and height to withers $(\mathrm{r}=0.32)$, height to back $(\mathrm{r}=0.36)$ and body length $(\mathrm{r}=0.41)$, which are values higher than values obtained in the present study. Low to moderate correlations between studied parameters were established by Fourie et al. (2005).

\section{Conclusion}

Based on obtained data it can be concluded that dominant rams had higher body mass, as well as greater testicular circumference. Social rank had no significant effect on measures of body development of rams, except chest girth, which was closely associated with body mass. However, moderate to high values of correlation coefficients between body mass and most of linear body measures, established in this research, indicate presence of the association between social ranking and size of the animals.

In presented study, rams were ranked based on competition for food. However, it should be taken into account that animals can compete in accordance to their motivation in any given moment, rather than in relation to any dominant hierarchy, and animals reared by men mainly have same access to sources of food. In that sense, and since there is no reliable test for determination of dominant hierarchy, in future studies, social ranking should be carried out from several 
various aspects and in this way it would be possible to determine more reliably major determinants of dominant behaviour of rams.

\section{Acknowledgment}

Research was financed by the Ministry of Education and Science of Republic of Serbia, project TR 31053

\section{Veza između socijalnog ranga, telesne mase, obima testisa i linearnih telesnih mera ovnova}

N. Maksimović, M. Žujović, S. Hristov, M. P. Petrović, B. Stanković, Z. Tomić, N. Stanišić

\section{Rezime}

Socijalni rang se odnosi na relativnu poziciju individue unutar dominantne hijerarhije koja se razvija u grupi. Kod ovnova, socijalni rang se najviše povezuje sa telesnom masom, veličinom tela i telesnom kondicijom. Međutim, iako se telesna masa generalno smatra jednom od glavnih determinanti socijalnog ranga, malo je istraživanja sprovedeno u cilju povezivanja socijalnog ponašanja i telesne razvijenosti ovih životinja. Cilj ovog istraživanja bio je da se utvrdi na koju način se mere telesne razvijenosti ovnova odnose prema uspostavljanju socijalne hijerarhije. Socijalni rang utvrđen je pomoću testa kompeticije na hranu kada su životinje bile u uzrastu od 4 i 7 meseci. Testiranje je obavljeno na ukupno 20 muških grla od čega je za dalje ispitivanje odabrano 12 grla (6 dominantnih i 6 submisivnih). Telesna masa i obim testisa mereni su u uzrastu od 4, 7, 12 i 18 meseci, a linearne telesne mere su izmerene u uzrastu od 12 i 18 meseci. Dominantna grla su imala veću telesnu masu i veći obim testisa. Socijalni rang nije imao značajan uticaj na linearne telesne mere ovnova, izuzev na meru obima grudi $(\mathrm{P}<0,05) \mathrm{u}$ oba kontrolna perioda. Telesna masa bila je umereno do visoko pozitivno povezana sa ispitivanim telesnim parametrima. Značajne pozitivne korelacije utvrđene su između telesne mase i dužine trupa $(\mathrm{r}=0,58 ; \mathrm{P}<0,01)$, širine grudi $(\mathrm{r}=0,44 ; \mathrm{P}<0,05)$, obima grudi $(\mathrm{r}=0,65 ; \mathrm{P}<0,01)$ i obima testisa $(\mathrm{r}=0,62$; $\mathrm{P}<0,01)$. Rezultati koji proizilaze iz ove studije ukazuju na opravdanost posmatranja mase tela kao jedne od glavnih determinanti socijalnog ranga, kao i na mogućnost ranijeg sazrevanja dominantnih jedinki. 


\section{References}

ABBASI MOKHTAR-ALI, GHAFOURI-KESBI F. (2011): Genetic (Co) variance components for body weight and body measurements in Makooei sheep. AsianAust. J. Anim. Sci., 24, 6, 739 - 743

AFOLAYAN A.R., ADEYINKA A.I., LAKPINI M.A.C. (2005): The estimation of live weight from body measurements in Yankasa sheep. Czech J. Anim. Sci., 51, 8, 343-348

ANDERSSON M. (1994): Sexual selection. Princenton, New Jersey: Princenton University press

BENYI K. (1997): Estimation of live weight from chest girth in pure and crossbred West African goats. Trop. Anim. Health Prod., 29, 124-128

COLTMAN D.W., O'DONOGHUE P., JORGENSON J.T., STROBECK C. (2002): Age-dependent sexual selection in bighorn rams. Proceedings of the Royal Society of London, series B, 269, 165-172

COTE S.D. (2000): Dominance hierarchies in female mountain goats: Stability, aggressiveness and determinants of rank. Behaviour, 137, 1541-1566

DREWS C. (1993): The concept and definition of dominance in animal behaviour. Behaviour, 125, 283-313

ELMAZ O., CIRIT U., DEMIR H. (2007): Relationship of testicular development with age, body weight, semen characteristics and testosterone in Kivirick ram lambs. South African Journal of Animal Science, 37, 4, 269-274

ENVOLDSEN C., KRITENSEN T. (1997): Estimation of body weight from body size measurements and body condition score in dairy cows. J. dairy sci., 80, 19881995

FOURIE J.P., NESER C.W.F., OLIVIER J.J., VAN DER WESTHUIZEN C. (2002): Relationship between production performance, visual appraisal and body measurements of young Dorper rams. South African Journal of Animal Science, $32,4,256-262$

FOURIE J.P., SCHWALBACH M.L., NESER C.W.F., GREYLING C.P.J. (2005): Relationship between body measurements and serum testosterone levels of Dorper rams. Small ruminant research, 56, 75-80

HIBRET A., TOE F., MUKASA-MUGERWA E., KASSA T., MARKOS T. (2001): Genital disorders, linear and testicular characteristic in Mens rams. Tropical animal health and production, 33, 3, 219-227

KOYUNCU M., KARA UZUN S., OZIS S., DURU S. (2005): Development of testicular dimensions and size and their relationship to age and body weight in growing Kivirick (Western Thrace) ram lambs. Czech J. Anim. Sci., 50, 6, 243-248 LINDSAY D.R., DUNSMORE D.G., WILLIAMS J.D., SYME G.J. (1976): Audience effects on the mating behaviour of rams. Anim. Behav., 24, 818-821 
LOBATO P.F.J., BEILHARZ G.R. (1979): Relation of social dominance and body size to intake of supplements in grazing sheep. Applied animal ethology, 5, 3, 233-239 McELLIGOTT A.G., GAMMELL M.P., HARTY H.C., PAINI D.R., MURPHY D.T., WALSH J.T., HAYDEN T.J. (2001): Sexual size dimorphism in fallow deer (Dama dama): Do larger, heavier males gain greater mating success? Behavioral ecology and sociobiology, 49, 266-272

MENGISTIE T., GIRMA A., SOLOMON G., SISAY L., ABEBE M., MARKOS T. (2010): Traditional management systems and linear body measurements of Washera sheep in the western highlands of the Amhara National Regional State, Ethiopia. Livestock research for rural development, 22, 9

MUKASA-MUGERWA E., EZAZ Z. (1992): Relationship of testicular growth and size to age, body weight and onset of puberty in Mens ram lambs. Theriogenology, 38, 979-988

PELLETIER F., BAUMAN J., FESTA-BIANCHET M. (2003): Fecal testosterone in bighorn sheep (Ovis canadensis): Behavioural and endocrine correlates. Canadian journal of zoology, 81, 1678-1684

PELLETIER F., FESTA-BIANCHET M. (2006): Sexual selection and social rank in bighorn rams. Animal Behaviour, 71, 649-655

PRESTON B.T., STEVENSON I.R., WILSON K. (2003): Overt and covert competition in a promiscuous mammal: The importance of weaponary and testes size to male reproductive success. Proceedings of the Royal Society of London, series B, 270, 633-640

RAJI A.O., IGWEBUIKE U.J., ALIYU J. (2008): Testicular biometry and its relationship with body weight of indigenous goats in a semi arid region of Nigeria. J. Agric. Biol. Sci., 3, 4, 6-9

REGE J.E.O., TOE F., MUKASA-MUGERWA E., TEMBELY S., ANINDO D., BAKER L.R., LAHLOU-KASSI A. (2000): Reproductive characteristics of Ethiopian highland sheep II: genetic parameters of semen characteristics and their relationships with testicular measurements in ram lambs. Sm. Rum. Res., 37, 173-187 SAPOLSKY R.M. (1993): The physiology of dominance in stable versus unstable social hierarchies. In Primate social conflict. State University of New York press, Albany, 171-204

SYNNOTT A.L., FULKERSON W.J. (1984): Influence of social interaction between rams on their serving capacity. Appl. Anim. Ethol., 11, 283-289

UNGERFELD R., GONSALEZ-PENSADO P.S. (2008): Social rank affects reproductive development in male lambs. Animal Reproduction Science, 109, 161-171 UNGERFELD R., LACUESTA L. (2010): Social rank during pre-pubertal development and reproductive performance of adult rams. Animal reproduction science, 121, 1-2, 101-105 